\title{
A systematic review of interventions to increase the use of standardized outcome measures by rehabilitation professionals
}

\begin{tabular}{|c|c|}
\hline Journal: & Clinical Rehabilitation \\
\hline Manuscript ID & CRE-2015-4909.R1 \\
\hline Manuscript Type: & Original Article \\
\hline Keywords: & $\begin{array}{l}\text { Outcome Assessment (Health Care), Occupational therapy, Physiotherapy, } \\
\text { Measurement }\end{array}$ \\
\hline Abstract: & $\begin{array}{l}\text { Objective: To determine the types and effectiveness of interventions to } \\
\text { increase the knowledge about, attitudes towards, and use of standardized } \\
\text { outcome measures in rehabilitation professionals. Data Sources: An } \\
\text { electronic search using Medline, EMBASE, PsycINFO, CINAHL, Ergonomics } \\
\text { Abstracts, Sports Discus. The search is current to February 2016. Study } \\
\text { Selection: All study designs testing interventions were included as were all } \\
\text { provider and patient types. Two reviewers independently conducted a title } \\
\text { and abstract review, followed by a full-text review. Data extraction: Two } \\
\text { reviewers independently extracted a priori variables and used consensus } \\
\text { for disagreements. Quality assessment was conducted using the } \\
\text { Assessment of Quantitative Studies published by the Effective Public Health } \\
\text { Practice Group. Data Synthesis: We identified } 11 \text { studies involving at least } \\
1200 \text { providers. Nine of the studies showed improvements in outcome } \\
\text { measure use rates but only three of these studies used an experimental or } \\
\text { quasi-experimental design. Eight of the studies used an educational } \\
\text { approach in the intervention and three used audit and feedback. Poor } \\
\text { intervention description and quality of studies limited recommendations. } \\
\text { Conclusions: Increased attention to testing interventions focused on known } \\
\text { barriers, matched to behavior change techniques, and with stronger } \\
\text { designs is warranted. }\end{array}$ \\
\hline
\end{tabular}

\section{SCHOLARONE ${ }^{\text {'w }}$}

Manuscripts 


\section{A systematic review of interventions to increase the use of standardized outcome measures by rehabilitation professionals}

Running Title: Systematic review of outcome measures

Heather L Colquhoun, Marie-Eve Lamontagne, Edward AS Duncan, Michelle Fiander, Catherine Champagne, and Jeremy M. Grimshaw

Correspondence to first author Heather Colquhoun: Department of Occupational Science and Occupational Therapy, University of Toronto, 160-500 University Ave, Toronto, Ontario, M5G 1V7, Canada. Email: heather.colquhoun@utoronto.ca. Ph: 416.978.1817 Fax: 416.946.8570 


\begin{abstract}
Objective: To determine the types and effectiveness of interventions to increase the knowledge about, attitudes towards, and use of standardized outcome measures in rehabilitation professionals. Data Sources: An electronic search using Medline, EMBASE, PsycINFO, CINAHL, Ergonomics Abstracts, Sports Discus. The search is current to February 2016. Study Selection: All study designs testing interventions were included as were all provider and patient types. Two reviewers independently conducted a title and abstract review, followed by a full-text review. Data extraction: Two reviewers independently extracted a priori variables and used consensus for disagreements. Quality assessment was conducted using the Assessment of Quantitative Studies published by the Effective Public Health Practice Group. Data Synthesis: We identified 11 studies involving at least 1200 providers. Nine of the studies showed improvements in outcome measure use rates but only three of these studies used an experimental or quasi-experimental design. Eight of the studies used an educational approach in the intervention and three used audit and feedback. Poor intervention description and quality of studies limited recommendations. Conclusions: Increased attention to testing interventions focused on known barriers, matched to behavior change techniques, and with stronger designs is warranted.
\end{abstract}


1

2

3

4

5

6

7

8

10

10

11

12

13

14

15

16

17

18

19

20

21

22

23

24

25

26

27

28

29

30

31

32

33

34

35

36

37

38

39

40

41

42

43

44

45

46

47

48

49

50

51

52

53

54

55

56

57

58

59

60

Key words: Allied health professional, Routine outcome measurement, Use of measures, Occupational therapy, Physical therapy, Physiotherapy, Speech and language therapy 


\section{Introduction}

Using standardized outcome measures as an integral component of health care practice is believed to improve clinical decision-making, care, and patient outcomes $(1,2)$. Yet, despite decades of encouragement (2), an apparent consensus on the need to use outcome measures (2, 3), and favorable clinicians' attitudes towards them (4), the use of outcome measures in health care practice including rehabilitation has not become routine practice (4-6). Surveys on the use of outcome measures by rehabilitation professionals consistently report low use rates and inconsistent application of measures across similar patient groups $(4,7-9)$.

The flaws associated with subjective judgement of patient improvement have been well documented (10). Clinicians tend to believe in the effectiveness of the treatment they administer and are, therefore, likely to be biased towards positively rating client improvement (11). If subjective judgment is the only method used to assess progress, clinician bias is increased. This supports the notion that the use of outcome assessment from sources other than clinician subjective judgement alone should lead to more accurate and realistic information on client progress, and subsequently, improved clinical decision-making, care and patient outcomes. Empirical support for the benefits of routine outcome measurement on occupational therapy practice $(12)$, client outcomes $(13,14)$, processes of care $(15)$, and communication $(16,17)$ exists. 
Studies that develop and test interventions to increase the use of standardized outcome measures are needed. To date, bridging this practice gap has focused on cross-sectional surveys identifying barriers to outcome measure use (7-9), including a systematic review of barriers and facilitators to the use of outcome measures (18). A key finding from the systematic review was that interventions to improve the use of outcome measurement in practice need to address barriers not only at the level of individual clinicians, but also at team and organizational levels. To our knowledge there are no reviews of interventions to increase the use of outcome measures in practice.

Consequently we conducted a systematic review to investigate the types and effectiveness of interventions studied that are aimed at increasing knowledge about, attitudes towards, and use of standardized outcome measures in the core (19) rehabilitation professionals; Occupational Therapy, Physiotherapy, Speech Language Pathology. A standardized outcome measure was defined as an instrument designed to describe, evaluate and/or predict an attribute $(20,21)$.

\section{Methods}


We undertook this review using Cochrane best practice methods in systematic reviews. Studies evaluating any intervention to improve knowledge about and/or change attitudes towards and/or increase the use of outcome measures in rehabilitation professionals (i.e., Occupational Therapy, Physiotherapy, Speech Language Pathology) focusing on any patient type were included. All quantitative study designs were included. We accepted any comparator (e.g. no intervention or other intervention). The systematic review is primarily aimed at rehabilitation but as limited intervention testing was anticipated, the search was extended to include interventions tested that targeted other health professionals (i.e., medicine, nursing, social work, dietetics and psychology) to determine if other areas have evaluated interventions to increase the use of measures in contexts that are relevant to rehabilitation.

Studies were excluded if the intervention was not evaluated, if the study was qualitative, if the study only investigated barriers and facilitators to outcome measure use, if the effect of using an outcome measure on care or patient outcomes was studied (as opposed to increasing use), and if conducted outside health care contexts, e.g. education. Studies that involved interventions applied to other health professionals were included if both reviewers agreed that the context was relevant to rehabilitation.

Search strategies were designed and run by an information specialist (MF). Strategies combined controlled vocabulary, when available, and keywords. Terms included, but were not 
limited to, outcome assessment health care, outcome and process assessment, psychiatric rating scales, health surveys. The following databases were initially searched in December 2013: Medline, EMBASE, PsycINFO (OVID); CINAHL, Ergonomics Abstracts, Sports Discus (Ebsco) and citation indexes and conference proceedings via Web of Knowledge. Neither date nor language limits were applied. We scanned reference lists of studies selected for inclusion. Full search strategies are available in Appendix A. An updated search, current to February 2016, was conducted to identify papers published since the initial search.

Study selection followed a two-step process. In the first, abstracts and titles were independently reviewed by two individuals (HC, MEL), followed by a consensus exercise to resolve discrepancies and arrive at a list of articles for a full text review. In the second step, full text articles were separately reviewed by the same two individuals followed by a consensus process to determine articles for inclusion in the review. For both steps, an interrater reliability analysis using the Kappa statistic was performed to determine rater consistency. Ordered categories were assumed (i.e. include, potentially include, do not include) and thus, weighted Kappa values were calculated (22).

Data extraction of the included articles was completed independently by two reviewers (HC, MEL) with discrepancies resolved using discussion. The data extraction forms and procedures were pilot tested in two studies to ensure clarity of items, interpretation of 
instructions, coding, and uniformity between data abstractors. The extraction was completed using an Excel spreadsheet. The following variables were collected: study descriptors (i.e., author, year, country in which data collection occurred, clinical setting, provider type, provider characteristics reported, patient characteristics reported, the types of outcome measures being promoted); study quality (i.e., study design, quality assessment data); intervention descriptors (i.e., if and how a theory was used for intervention design, a description of the intervention being used, whether any efforts were undertaken to sustain the use of the measures after the study was over), and study results (i.e., study result, sample size of provider and patients, statistical technique used).

Quality assessment was achieved using the quality assessment tool for Quantitative Studies published by the Effective Public Health Practice Group (23). This approach was chosen as it is includes multiple quantitative study designs similar to the range of designs anticipated in this review, has an accompanying dictionary of definitions and instructions, and has been used in previous systematic reviews that have focused on rehabilitation (24). The tool involves a global rating of quality based on eight sources of bias: selection bias, study design, confounders, blinding, data collection methods, withdrawals and dropouts. Two independent raters (HC, MEL) completed the tool and final scores were determined based on consensus. 
A narrative and descriptive summary of all of the descriptors was undertaken. Statistical analysis of the data was planned if results permitted (mean differences and confidence intervals for continuous data; odds ratio's and confidence intervals for dichotomous data).

\section{Results}

Searching yielded 3,907 records in the initial search and an additional 2083 records as part of the updated search for a total of 5,990 records that underwent title and abstract screening. Fifty articles were selected for full-text review. Thirty-nine articles were excluded in the full-text review resulting in the final inclusion of eleven studies. Reasons for exclusion based on full text review included not involving an intervention to increase measure use, not being relevant to rehabilitation (i.e. the use of pain scales by nurses in intensive care units), not including an evaluation of the intervention, commentaries, and studies pertaining to barriers assessment. Two studies could not be located. For the title and abstract review, the weighted Kappa statistic was $>$ .4 (moderate agreement), and for the full text review, the Kappa statistic was $>.7$ (good agreement) (22). A PRIMSA flow diagram, documenting all stages of study selection is in Figure 1.

All included studies specifically targeted the intervention to at least one of the three core rehabilitation providers with two exceptions. Kisely and colleagues stated the target for the 
intervention as 'outpatient mental health professionals' (25). Since occupational therapy can be considered a core team member for outpatient mental health (26), we chose to include this article. The second study directed the intervention at prosthetists (27). Since the outcome measures used were focused on functional mobility and for the purposes of measuring changes in functional mobility due to prosthetist treatment, we determined that this study was relevant to rehabilitation.

\section{Study descriptors}

The studies were published between 2000 to 2016 . The year with the greatest number of studies, $n=3$ (27-29), was 2015. There were a range of clinical study settings. For example, one was in outpatient mental health (25), one in both private practices and nursing homes (29), and one in the area of chronic pain (30). Three of the studies covered both acute and community contexts: stroke (31), brain injury (32) and non-specified (33) (i.e. any area of practice in which a measure was used). Two of the studies were in an outpatient pediatric setting $(28,34)$. Seven of the studies targeted physiotherapists only $(1,28,29,31,33-35)$, one study occurred with community mental health professions (unspecified but occupational therapy assumed) (25), one study each targeted occupational therapists only (30) and prosthetists only (27), and one study involved physiotherapists, occupational therapists and speech-language pathologists (32). While 


\section{Study Quality}

There was one randomized controlled trial (31), two controlled before and after studies $(29,35)$, seven before and after studies $(1,25,27,28,30,33,34)$, and one retrospective cohort study (32). Nine of the eleven studies had an overall quality rating of weak. Two studies had an overall rating of moderate $(31,35)$. Only one of the studies had strong ratings for any of the six 
components that made up the overall quality rating (31). Of the nine studies that were rated as weak, one was weak in all categories (30) and the other eight were weak in either four or five of the six categories $(1,25,27-29,32-34)$. One of the studies that had on overall rating of moderate (31) used an experimental design with randomization but was limited by a small sample size, i.e. 15 experimental and 15 control professionals. See Table II for a summary of the quality assessment.

\section{Intervention descriptors}

Five studies were informed by a theory or knowledge translation framework. Two studies $(28,34)$ applied the Knowledge to Action Framework $(36)$ to guide the steps they undertook to change practice. Two other studies $(29,35)$ also used a framework to provide guidance but chose Grol and Wensing's Five-step Implementation Model (37). The fifth study (31) used theories by Grol (38) and Ajzen (39) to gain insights into how education can change behavior and to identify barriers and facilitators to behavior change.

The interventions to increase knowledge of, attitudes towards and the use of outcome measures, ranged in content and intensity. Nine of the eleven studies applied educational strategies in the form of workshops or seminars $(1,27-32,34,35)$. The two that did not do this $(25,33)$ applied indirect education through the dissemination of materials. One of the studies that 
employed direct educational strategies tested two different types of strategies head-to-head: education delivered by experts versus non experts (31). Three of the studies applied audit and feedback in combination with either education (32) or dissemination of materials $(25,33)$. About half, five of the eleven, used greater than 3 strategies $(1,28,30,34,35)$. Four studies reported a dose for all elements of the intervention. Specifically, these were reported as: audit and feedback plus education for 25 weekly session (32); audit and feedback plus education on one occasion (33); four interactive half-day sessions over 4-5 months and provision of a toolkit on one occasion (29); five two-hour evening education sessions over 14 weeks (31). Of the remaining seven that did not provide full information on the dose of the intervention, four $(28,30,34,35)$ provided some but not all information (ie. the length of time of the workshop but not how many reminders were provided) (35), and three studies reported no details on the dose of the intervention $(1,25,27)$. Only one of the studies did not measure use rates, measuring confidence in using measures (27). Of the other ten studies that measured use rates, three also measured attitudes towards measures $(1,29,35)$ and two also measured knowledge of measures $(28,34)$. Only two of the eleven studies included efforts to sustain the use of the measures after the study had completed; one study measuring at 12 and 18 months after the intervention (34) and one at 8 months after the intervention (29). 


\section{Study Results}

Of the eight studies that employed educational strategies and measured the use rates of outcome measures, seven found improvements $(1,28-31,34,35)$. The two studies that employed indirect educational strategies (i.e., dissemination of guidelines) also reported improvements in use rates $(25,33)$. Both of these studies used audit and feedback in combination with the indirect educational strategies. The one study that used educational strategies but did not show an effect was the study that used audit and feedback in combination with education (32). The two studies with the highest quality ratings found improvements in use rates. The first of these studies evaluated a 10-hour educational strategy (31) and the other study evaluated an intervention with five strategies that included dissemination of guidance, a 3-hour educational workshop, a website of guideline and measures, email reminders, and email and telephone support (35). Of the two studies that attempted to measure if effects were sustained over time, one found effects that were maintained at 18 months (34), the other did not (29).

Three studies included secondary measurement of attitudes. One found that attitudes became less positive after the intervention (1), the other two found no change in attitudes (29, $35)$. The two studies that measured knowledge found improvements $(28,34)$. Two studies used both actual and self-report rates of measure use: one found consistent and positive results for 


\section{Discussion}

Eleven studies were identified that met the inclusion criteria; all but one pertained to rehabilitation and/or outpatient mental health services (providers unspecified). Seven of the eleven studies used physiotherapists as the target for the intervention. One study had prosthetists as the target for the intervention (27). Overall, improvements in use rates of outcome measures occurred in nine of the ten studies that measured use rates $(1,25,28-31,33-35)$ although five of these ten stated effects as changes in percent adherence without any statistical testing $(1,25,29$, $30,33)$. Whilst the studies in this review do appear to have had some effect, strong conclusions cannot be made due to weak study designs, poor intervention descriptions, and a limited number of studies.

Despite the importance of routine outcome measurement being recognized for over 20 years (18), the quantity and quality of research conducted to date to improve routine use of outcome measurement is poor. Only one study in this review used an experimental design with randomization and most interventions would be difficult to replicate given the quality of 
reporting. Consequently this review is unable to draw any definitive conclusions. Focused studies in key clinical areas, with stronger causal designs and more detailed intervention descriptions are therefore urgently required. Consideration of additional improvements to intervention design and evaluation such as process evaluations (40), design based on known barriers (41), and deliberate stakeholder engagement (42) should also be considered.

The majority of interventions included in this review adopted education approaches. This was the same finding as a systematic review of knowledge translation interventions, designed to translate research into allied health professional practice (24). The over-reliance of education as a strategy to bring about behavior change is widespread, and has been described as an 'education reflex'(43) by Pailey and colleagues. While systematic reviews of continuing education (44) do show that educational activities can lead to improvements in practice, they typically only address knowledge barriers, and do not necessarily target other, and sometimes more important barriers such as skills or professional role. Whilst the education studies in this review do appear to have had some effect, a reliance on education is unlikely to optimize use of routine outcome measures.

Three studies in this review used audit and feedback to improve routine outcome measurement use $(25,32,33)$. Audit and feedback shows promise as an intervention to change people's behavior (45). It can take many forms (e.g. verbal or written), have differing sources (e.g. colleague, or manager) and can contain information on varied content (e.g. processes of 
care or patient outcomes) (45). Using audit and feedback to improve routine outcome measurement is one approach among others that merits rigorous evaluation.

Education and audit and feedback mechanisms, however, are only one of a series of evidence-based behavior change techniques (46). A variety of other strategies exist, and have potential to make a greater difference to outcome measurement usage in practice. In particular, tools like the Theoretical Domains Framework (47) and the Behaviour Change Technique matrix (46), a theory-based process of matching known barriers to behavior change techniques could be useful to the uptake of outcome measures. In addition, these approaches allow for the specification of the relationship between the barriers to be addressed and the intervention components.

The focus of each of the interventions included in this study was targeted at the individual clinician level. This is likely to be insufficient, as evidence from a previous review of routine outcome measurement literature suggests that the reasons for failure to routinely implement outcome measurement are multi-factorial, and occur at different levels in an organization: individual, team, and organization (18). Future studies should, therefore, evaluate behavioural change interventions that address each of these levels to maximize their potential effectiveness. This could include even broader levels such as the socio-political context (37). 
As with all reviews, this study has limitations. In order to locate all possible studies, the search strategy was kept broad and a significant number of abstracts were screened. However, it is still possible that papers were missed, particularly in a field as broad as 'outcome measurement'. Also, rehabilitation is a large domain that is encompassed in many settings and difficult to objectively delimit. It is also possible that many outcome measure efforts occur as local quality improvement efforts that may or may not be in peer-reviewed literature. A search of grey literature might have addressed this although it is not clear that study quality would have been high given what was found in the peer-reviewed literature. In addition, there could be other evidence outside of the domain of rehabilitation and health (e.g. education) that could yield additional insights but were not necessarily the focus of this review.

In conclusion, our systematic review of interventions to increase outcome measure use in the field of rehabilitation yielded only eleven studies. Study designs were weak and interventions descriptions were poor. Understanding how to improve the use of outcome measures in rehabilitation will require stronger study designs and improvements to the design and reporting of interventions. Careful consideration of potentially useful intervention components outside of education is warranted, as is testing audit and feedback, and the selection of interventions components in keeping with known barriers to outcome measure use. 


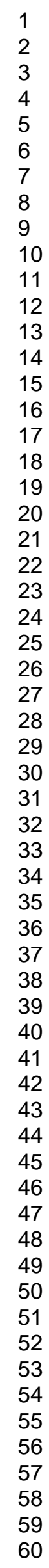

http://mc.manuscriptcentral.com/clinrehab 


\title{
Clinical Messages
}

- Minimal testing of interventions to increase the use of outcome measures in rehabilitation has been undertaken

- Increased attention to testing interventions focused on known barriers, matched to behavior change techniques, and with stronger designs is needed

Acknowledgements: This study was funded by Knowledge Translation Canada (KT Canada). HLC is supported by a Canadian Institutes of Health Research Fellowship Award. JMG holds a Canada Research Chair in Health Knowledge Transfer and Uptake

\begin{abstract}
Author Contributions: HLC contributed to the conception and design of the study, the acquisition, analysis and interpretation of data, and drafted the manuscript. MEL and CC contributed to the acquisition, analysis and interpretation of data in this study. ED contributed to the design of this study as well as the interpretation of the data. MF contributed to the design and conduct of the search strategy. JG contributed to the conception and design of the study as well as the interpretation of the data. All author's contributed edits to, read and approved the final version of the manuscript.
\end{abstract}


1. Abrams D, Davidson M, Harrick J, Harcourt P, Zylinski M, Clancy J. Monitoring the change: current trends in outcome measure usage in physiotherapy. Manual therapy. 2006;11(1):46-53.

2. Law MC, Baum CM, Dunn W. Measuring occupational performance: Supporting best practice in occupational therapy: Slack Incorporated; 2005.

3. Heinemann AW. Putting outcome measurement in context: A rehabilitation psychology perspective. Rehabilitation psychology. 2005;50(1):6.

4. Jette DU, Halbert J, Iverson C, Miceli E, Shah P. Use of standardized outcome measures in physical therapist practice: perceptions and applications. Physical therapy. 2009;89(2):125-35.

5. Gilbody SM, HOUSE AO, SHELDON TA. Psychiatrists in the UK do not use outcomes measures National survey. The British Journal of Psychiatry. 2002;180(2):101-3.

6. Michlovitz SL, LaStayo PC, Alzner S, Watson E. Distal radius fractures: therapy practice patterns. Journal of Hand Therapy. 2001;14(4):249-57.

7. Douglas H, Swanson C, Gee T, Bellamy N. Outcome measurement in Australian rehabilitation environments. Journal of rehabilitation medicine. 2005;37(5):325-9.

8. Haigh R, Tennant A, Biering-Sorensen F, Grimby G, Marincek C, Phillips S, et al. The use of outcome measures in physical medicine and rehabilitation within Europe. Journal of rehabilitation medicine. 2001;33(6):273-8.

9. Blenkiron EL. Uptake of standardised hand assessments in rheumatology: why is it so low? The British Journal of Occupational Therapy. 2005;68(4):148-57.

10. Garb HN. Clinical Judgment and Decision Making*. Clinical Psychology. 2005;1(1):67.

11. Kaptchuk TJ. Intentional ignorance: a history of blind assessment and placebo controls in medicine. Bulletin of the History of Medicine. 1998;72(3):389-433.

12. Colquhoun HL, Letts LJ, Law MC, MacDermid JC, Missiuna CA. Administration of the Canadian Occupational Performance Measure: effect on practice. Canadian journal of occupational therapy Revue canadienne d'ergotherapie. 2012;79(2):120-8.

13. Lambert MJ, Harmon C, Slade K, Whipple JL, Hawkins EJ. Providing feedback to psychotherapists on their patients' progress: clinical results and practice suggestions. Journal of clinical psychology. 2005;61(2):165-74.

14. Hilarius DL, Kloeg PH, Gundy CM, Aaronson NK. Use of health-related quality-of-life assessments in daily clinical oncology nursing practice. Cancer. 2008;113(3):628-37.

15. Espallargues M, Valderas JM, Alonso J. Provision of feedback on perceived health status to health care professionals: a systematic review of its impact. Medical care. 2000;38(2):175-86.

16. Detmar SB, Muller MJ, Schornagel JH, Wever LD, Aaronson NK. Health-related quality-of-life assessments and patient-physician communication: a randomized controlled trial. Jama. 2002;288(23):3027-34.

17. Santana M-J, Feeny D, Johnson JA, McAlister FA, Kim D, Weinkauf J, et al. Assessing the use of health-related quality of life measures in the routine clinical care of lung-transplant patients. Quality of Life Research. 2010;19(3):371-9. 
18. Duncan EA, Murray J. The barriers and facilitators to routine outcome measurement by allied health professionals in practice: a systematic review. BMC health services research. 2012;12(1):96.

19. Rochette A, Korner-Bitensky N, Desrosiers J. Actual vs best practice for families post-stroke according to three rehabilitation disciplines. Journal of rehabilitation medicine. 2007;39(7):513-9.

20. Law M. Measurement in occupational therapy: Scientific criteria for evaluation. Canadian Journal of Occupational Therapy. 1987;54(3):133-8.

21. Association AER, Association AP, Education NCoMi, Educational JCoSf, Testing P. Standards for educational and psychological testing: Amer Educational Research Assn; 1999.

22. Landis JR, Koch GG. The measurement of observer agreement for categorical data. biometrics. 1977:159-74.

23. Project EPHP. Quality assessment tool for quantitative studies [http://www.ephpp.ca/Tools.html].

24. Scott SD, Albrecht L, O'Leary K, Ball G, Hartling L, Hofmeyer A, et al. Systematic review of knowledge translation strategies in the allied health professions. Implementation science : IS. 2012;7(1):70-.

25. Kisely S, Campbell LA, Robertson H, Crossman D, Martin K, Campbell J. Routine measurement of mental health service outcomes: Health of the Nation Outcome Scales in Nova Scotia. Psychiatric Bulletin. 2008;32(7):248-50.

26. Long C, Cronin-Davis J. Occupational therapy evidence in practice for mental health: Blackwell Pub.; 2006.

27. Gaunaurd I, Spaulding SE, Amtmann D, Salem R, Gailey R, Morgan SJ, et al. Use of and confidence in administering outcome measures among clinical prosthetists: Results from a national survey and mixed-methods training program. Prosthetics and orthotics international. 2015;39(4):314-21. 28. Schreiber J, Marchetti GF, Racicot B, Kaminski E. The use of a knowledge translation program to increase use of standardized outcome measures in an outpatient pediatric physical therapy clinic: administrative case report. Physical therapy. 2015;95(4):613-29.

29. Swinkels RA, Meerhoff GM, Custers JW, van Peppen RP, Beurskens AJ, Wittink H. Using Outcome Measures in Daily Practice: Development and Evaluation of an Implementation Strategy for Physiotherapists in the Netherlands. Physiotherapy Canada. 2015;67(4):357-64.

30. Cook C, McCluskey A, Bowman J. Occupational therapists report increased use of outcome measures after participation in an education programme. The British Journal of Occupational Therapy. 2007;70(11):487-92.

31. Van Peppen R, Schuurmans M, Stutterheim E, Lindeman E, Van Meeteren N. Promoting the use of outcome measures by an educational programme for physiotherapists in stroke rehabilitation: a pilot randomized controlled trial. Clinical rehabilitation. 2009;23(11):1005-17.

32. Bland MD, Sturmoski A, Whitson M, Harris H, Connor LT, Fucetola R, et al. Clinician adherence to a standardized assessment battery across settings and disciplines in a poststroke rehabilitation population. Archives of physical medicine and rehabilitation. 2013;94(6):1048-53. e1.

33. Sumner M, Mead J, ten Hove R. Audit and re-audit of the CSP core standards of physiotherapy practice. Physiotherapy. 2000;86(10):512-6.

34. Russell DJ, Rivard LM, Walter SD, Rosenbaum PL, Roxborough L, Cameron D, et al. Using knowledge brokers to facilitate the uptake of pediatric measurement tools into clinical practice: a beforeafter intervention study. Implementation science : IS. 2010;5(1):92. 
35. Käll I, Larsson ME, Bernhardsson S. Use of outcome measures improved after a tailored implementation in primary care physiotherapy: a prospective, controlled study. Journal of Evaluation in Clinical Practice. 2016.

36. Graham ID, Logan J, Harrison MB, Straus SE, Tetroe J, Caswell W, et al. Lost in knowledge translation: time for a map? The Journal of continuing education in the health professions. 2006;26(1):1324.

37. Grol R, Wensing M, Eccles M. Improving patient care: the implementation of change in clinical practice. 2005.

38. Grol R, Grimshaw J. From best evidence to best practice: effective implementation of change in patients' care. The lancet. 2003;362(9391):1225-30.

39. Ajzen I. The theory of planned behavior. Organizational behavior and human decision processes. 1991;50(2):179-211.

40. Ramsay CR, Thomas RE, Croal BL, Grimshaw JM, Eccles MP. Using the theory of planned behaviour as a process evaluation tool in randomised trials of knowledge translation strategies: A case study from UK primary care. Implementation science : IS. 2010;5(1):71.

41. Grimshaw JM, Eccles MP, Lavis JN, Hill SJ, Squires JE. Knowledge translation of research findings. Implementation science : IS. 2012;7(1):50.

42. Graham ID, Tetroe J. Some theoretical underpinnings of knowledge translation. Academic Emergency Medicine. 2007;14(11):936-41.

43. Paley J. Distributed cognition and the education reflex. Educating Professionals: Towards a Philosophy of Nursing and Health Care Professional Education, Macmillan, London. 2007:143-60.

44. Davis D, O'Brien MAT, Freemantle N, Wolf FM, Mazmanian P, Taylor-Vaisey A. Impact of formal continuing medical education: do conferences, workshops, rounds, and other traditional continuing education activities change physician behavior or health care outcomes? Jama. 1999;282(9):867-74. 45. Ivers N, Jamtvedt G, Flottorp S, Young JM, Odgaard-Jensen J, French SD, et al. Audit and feedback: effects on professional practice and healthcare outcomes. Cochrane Database Syst Rev. 2012;6.

46. Michie S, Richardson M, Johnston M, Abraham C, Francis J, Hardeman W, et al. The behavior change technique taxonomy ( $\mathrm{v} 1$ ) of 93 hierarchically clustered techniques: building an international consensus for the reporting of behavior change interventions. Annals of behavioral medicine. 2013;46(1):81-95.

47. Michie S, Johnston M, Abraham C, Lawton R, Parker D, Walker A, et al. Making psychological theory useful for implementing evidence based practice: a consensus approach. Quality \& safety in health care. 2005;14(1):26-33. 
Figure 1 -PRISMA diagram

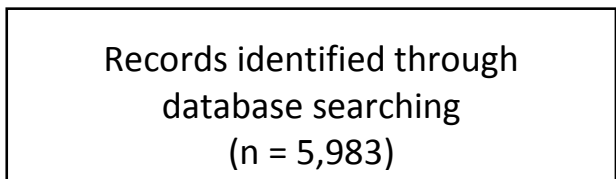

$$
(n=5,983)
$$

Additional records identified through other sources

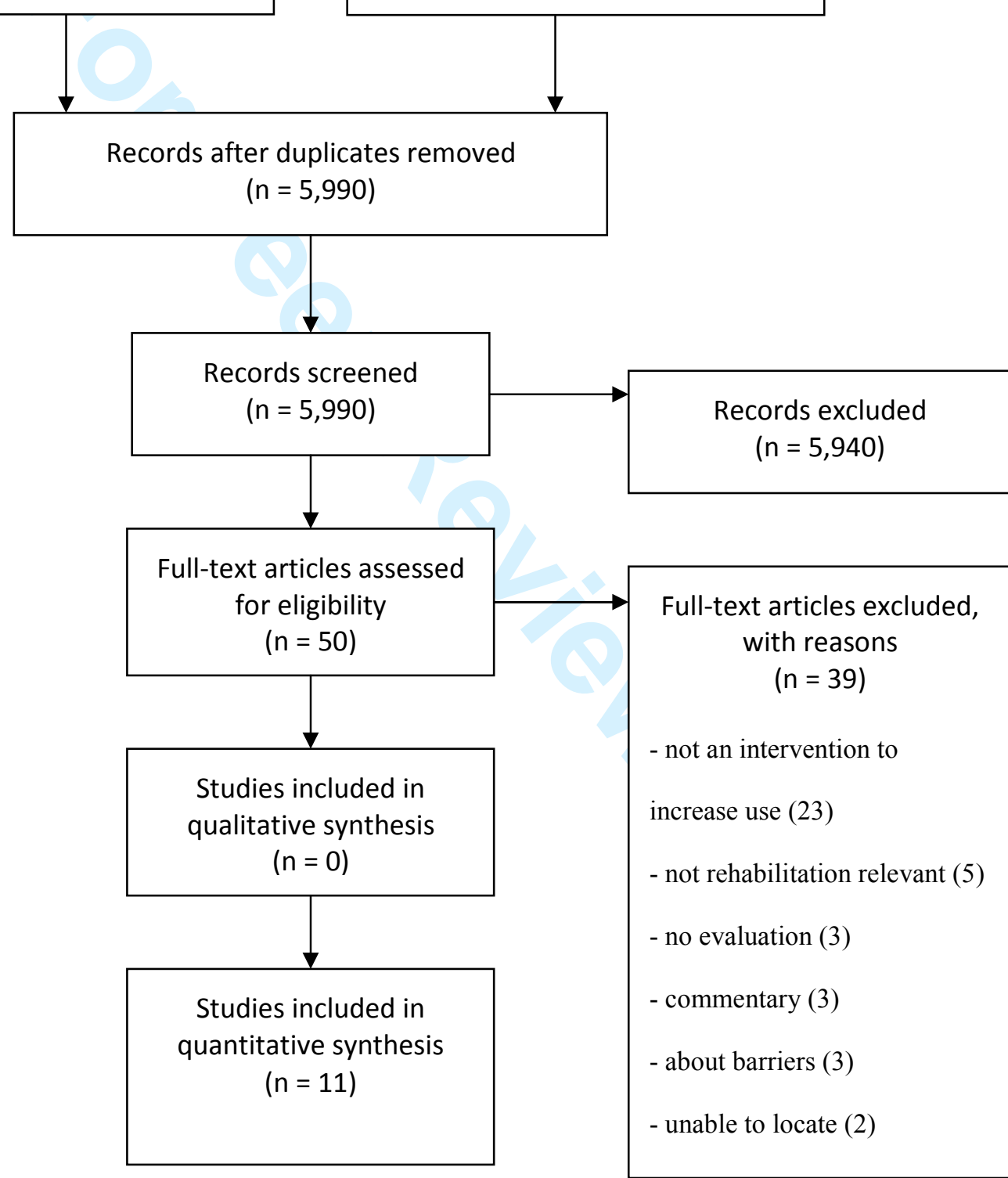


Table I Summary of included studies, $n=11$

\begin{tabular}{|c|c|c|c|c|c|c|}
\hline $\begin{array}{l}\text { Author, } \\
\text { year, } \\
\text { country }\end{array}$ & $\begin{array}{l}\text { Provider, } \\
\text { provider } \\
\text { sample size }\end{array}$ & Study design & Setting & $\begin{array}{l}\text { Outcome } \\
\text { measure being } \\
\text { used in } \\
\text { practice }\end{array}$ & Intervention & Results \\
\hline $\begin{array}{l}\text { Abrams, } \\
2006(1) \\
\text { Australia }\end{array}$ & $\begin{array}{l}\text { PT } \\
n=154\end{array}$ & $\begin{array}{l}\text { Before and } \\
\text { after study }\end{array}$ & $\begin{array}{l}\text { Community, } \\
\text { outpatient }\end{array}$ & $\begin{array}{l}\text { Multiple, } \mathrm{n}=9 \\
\text { (e.g. Oswestry, } \\
\text { Quebec) }\end{array}$ & $\begin{array}{l}\text { Education, } \\
\text { dissemination } \\
\text { of guidance, } \\
\text { mandated } \\
\text { processes of } \\
\text { care, } \\
\text { resources, } \\
\text { peer support } \\
\text { Dose: not } \\
\text { reported }\end{array}$ & $\begin{array}{l}\text { Use: Percent } \\
\text { difference was } \\
\text { positive for seven of } \\
\text { nine tests } \\
\text { (self-report) } \\
\text { Attitude: Total attitude } \\
\text { score show less } \\
\text { positive attitudes, } \\
\mathrm{p}=.02,27.1 \text { (SD 4.8) } \\
\text { to } 25.8 \text { (SD 1.1) }\end{array}$ \\
\hline $\begin{array}{l}\text { Bland, } 2013 \\
(32) \\
\text { United } \\
\text { States }\end{array}$ & $\begin{array}{l}\text { OT, PT SLP } \\
\mathrm{n}=118\end{array}$ & $\begin{array}{l}\text { Retrospective } \\
\text { cohort study }\end{array}$ & $\begin{array}{l}\text { Acquired } \\
\text { brain injury } \\
\text { Acute care, } \\
\text { inpatient, } \\
\text { outpatient }\end{array}$ & $\begin{array}{l}\text { Multiple, } \mathrm{n}= \\
39 \\
\text { (Brain } \\
\text { Recovery Core } \\
\text { assessments) }\end{array}$ & $\begin{array}{l}\text { A\&F + } \\
\text { educational } \\
\text { staff meetings } \\
\text { Dose: } 25 \\
\text { meetings over } \\
17 \text { months }\end{array}$ & $\begin{array}{l}\text { Use: No effect } \\
\text { (actual use) }\end{array}$ \\
\hline $\begin{array}{l}\text { Cook, } 2007 \\
(30) \\
\text { Australia }\end{array}$ & $\begin{array}{l}\text { OT } \\
n=36\end{array}$ & $\begin{array}{l}\text { Before and } \\
\text { after study }\end{array}$ & $\begin{array}{l}\text { Chronic pain, } \\
\text { setting } \\
\text { unspecified }\end{array}$ & $\begin{array}{l}\text { Multiple, } \mathrm{n}=9 \\
\text { (e.g., Visual } \\
\text { Analogue } \\
\text { Scale, Goal } \\
\text { Attainment } \\
\text { Scale) }\end{array}$ & $\begin{array}{l}\text { Educational } \\
\text { workshop }+ \\
\text { resource } \\
\text { package of } \\
\text { measures }+ \\
\text { follow-up } \\
\text { support } \\
\text { Dose: } 1 \text { day }\end{array}$ & $\begin{array}{l}\text { Use: Increased from } \\
66 \% \text { to } 91 \%(p=0.012) \\
\text { (self-report) }\end{array}$ \\
\hline
\end{tabular}




\begin{tabular}{|c|c|c|c|c|c|c|}
\hline & & & & & $\begin{array}{l}\text { workshop }+4 \\
\text { months of } \\
\text { follow-up }\end{array}$ & \\
\hline $\begin{array}{l}\text { Gaunaurd, } \\
2015(27) \\
\text { United } \\
\text { States }\end{array}$ & $\begin{array}{l}\text { Prosthetists } \\
\mathrm{n}=79\end{array}$ & $\begin{array}{l}\text { Before and } \\
\text { after study }\end{array}$ & $\begin{array}{l}\text { Prosthetic } \\
\text { clinics }\end{array}$ & $\begin{array}{l}\text { Multiple, } n=2 \\
\text { (i.e., Timed Up } \\
\text { and Go, } \\
\text { Amputee } \\
\text { Mobility } \\
\text { Predictor }\end{array}$ & $\begin{array}{l}\text { Educational } \\
\text { workshop } \\
\text { Dose not } \\
\text { reported }\end{array}$ & $\begin{array}{l}\text { Confidence: improved } \\
\text { confidence for } \\
\text { administering both } \\
\text { measures } p<.0001 \\
\text { (self-report) }\end{array}$ \\
\hline $\begin{array}{l}\text { Käll, } \\
\text { 2016(35) } \\
\text { Sweden }\end{array}$ & $\begin{array}{l}\text { PT } \\
n=425 \text { ( } 256 \\
\text { intervention and } \\
163 \text { control })\end{array}$ & $\begin{array}{l}\text { Controlled } \\
\text { before and } \\
\text { after study }\end{array}$ & $\begin{array}{l}\text { Low back } \\
\text { pain, setting } \\
\text { unspecified }\end{array}$ & $\begin{array}{l}\text { Multiple, } n=4 \\
\text { (e.g., Neck } \\
\text { Disability } \\
\text { Index, } \\
\text { Disabilities of } \\
\text { the Arm, } \\
\text { Shoulder and } \\
\text { Hand) }\end{array}$ & $\begin{array}{l}\text { Dissemination } \\
\text { of guidance }+ \\
\text { educational } \\
\text { workshop }+ \\
\text { website of } \\
\text { guideline and } \\
\text { measures + } \\
\text { email } \\
\text { reminders + } \\
\text { email and } \\
\text { telephone } \\
\text { support } \\
\text { Dose: 3-hour } \\
\text { workshop }\end{array}$ & $\begin{array}{l}\text { Use: } 55 \% \text { in } \\
\text { intervention group } \\
\text { report use of measures } \\
\text { frequently versus } 36 \% \\
\text { in control group ( } 95 \% \\
\text { CI } 6.2 \% \text { to } 31 \% \text { ) } \\
\text { (self-report) } \\
\frac{\text { Attitudes: No effect, }}{\mathrm{p}=0.857}\end{array}$ \\
\hline $\begin{array}{l}\text { Kisely, } 2008 \\
(25) \\
\text { Canada }\end{array}$ & $\begin{array}{l}\text { Providers } \\
\text { providing } \\
\text { 'mental health } \\
\text { services' }\end{array}$ & $\begin{array}{l}\text { Before and } \\
\text { after study }\end{array}$ & $\begin{array}{l}\text { Community } \\
\text { outpatient } \\
\text { (mental } \\
\text { health } \\
\text { services) }\end{array}$ & $\begin{array}{l}\text { Multiple, } \mathrm{n}= \\
\text { not specified } \\
\text { (Health of the } \\
\text { Nation } \\
\text { Outcome } \\
\text { Scales } \\
\text { [HoNOS]) }\end{array}$ & $\begin{array}{l}\text { A\&F }+ \\
\text { dissemination } \\
\text { of educational } \\
\text { materials } \\
\text { Dose: not } \\
\text { reported }\end{array}$ & $\begin{array}{l}\text { Use: Completion rate } \\
\text { went from } 61 \% \text { to } \\
86 \% \\
\text { (actual use) }\end{array}$ \\
\hline
\end{tabular}




\begin{tabular}{|c|c|c|c|c|c|c|}
\hline $\begin{array}{l}\text { Russell, } \\
\text { 2010(34) } \\
\text { Canada }\end{array}$ & $\begin{array}{l}\mathrm{PT} \\
\mathrm{n}=122\end{array}$ & $\begin{array}{l}\text { Before and } \\
\text { after study }\end{array}$ & $\begin{array}{l}\text { Pediatric } \\
\text { outpatient }\end{array}$ & $\begin{array}{l}\text { Multiple, } n=4 . \\
\text { (i.e., GMFCS, } \\
\text { GMFM- } 88 \text { and } \\
\text { GMFM-66, } \\
\text { MGC) }\end{array}$ & $\begin{array}{l}\text { Knowledge } \\
\text { Broker } \\
\text { (multiple } \\
\text { activities } \\
\text { including } \\
\text { education) } \\
\text { Dose: } 6 \\
\text { months }\end{array}$ & $\begin{array}{l}\text { Use: Significantly } \\
\text { improved for } 3 \text { of } 4 \\
\text { measures. } \\
\text { Knowledge: } \\
\text { Significantly } \\
\text { improved for all } \\
\text { measures. } \\
\text { (self-report) }\end{array}$ \\
\hline $\begin{array}{l}\text { Schreiber, } \\
2015(28) \\
\text { United } \\
\text { States }\end{array}$ & $\begin{array}{l}\mathrm{PT} \\
\mathrm{n}=17\end{array}$ & $\begin{array}{l}\text { Before and } \\
\text { after study }\end{array}$ & $\begin{array}{l}\text { Pediatric } \\
\text { outpatient }\end{array}$ & $\begin{array}{l}\text { n=7; GMFM- } \\
\text { 88/GMFM-66, } \\
\text { MGC,GMFCS, } \\
\text { PEDI, TUG, } \\
\text { TUDS, } 30 \\
\text { second walk } \\
\text { test) }\end{array}$ & $\begin{array}{l}\text { Educational } \\
\text { workshop }+ \\
\text { resource } \\
\text { materials }+ \\
\text { video } \\
\text { demonstration } \\
+ \text { on-line } \\
\text { discussion } \\
\text { Dose: } 2 \text { hour } \\
\text { workshop }\end{array}$ & $\begin{array}{l}\text { Use (self-report): } \\
\text { mean change of } 11.6 \\
\text { (SD 5.9), }<<.001 . \\
\text { Use (actual): increase } \\
\text { in frequency counts of } \\
\text { measures. } \\
\text { Knowledge (self- } \\
\text { report): } 54.1(\mathrm{SD} 13.5) \\
\text { at baseline and } 81.8 \\
\text { (SD12.7) at follow-up }\end{array}$ \\
\hline $\begin{array}{l}\text { Sumner, } \\
2000(33) \\
\text { United } \\
\text { Kingdom }\end{array}$ & $\begin{array}{l}\text { PT } \\
\mathrm{n}=\text { not } \\
\text { specified }\end{array}$ & $\begin{array}{l}\text { Before and } \\
\text { after study }\end{array}$ & $\begin{array}{l}8 \text { settings } \\
\text { across } \\
\text { multiple } \\
\text { sectors (e.g. } \\
\text { acute, } \\
\text { community, } \\
\text { private } \\
\text { practices) }\end{array}$ & $\begin{array}{l}\text { Not specified } \\
\text { (could be any } \\
\text { measure) }\end{array}$ & $\begin{array}{l}\text { A\&F }+ \\
\text { dissemination } \\
\text { of education } \\
\text { materials } \\
\text { Dose: } \\
\text { frequency of } \\
\text { one }\end{array}$ & $\begin{array}{l}\text { Use: Documented } \\
\text { outcome measure use } \\
\text { increased from } 44 \% \text { to } \\
79 \% \text {. } \\
\text { (actual use) }\end{array}$ \\
\hline $\begin{array}{l}\text { Swinkels, } \\
\text { 2015(29) } \\
\text { Netherlands }\end{array}$ & $\begin{array}{l}\text { PT } \\
\mathrm{n}=261 \text { (175 for } \\
\text { Intervention and } \\
86 \text { for control) }\end{array}$ & $\begin{array}{l}\text { Controlled } \\
\text { before and } \\
\text { after study }\end{array}$ & $\begin{array}{l}\text { Private } \\
\text { Practice or } \\
\text { Nursing } \\
\text { Homes }\end{array}$ & $\begin{array}{l}\text { Not specified. } \\
\text { Private } \\
\text { practice (19 } \\
\text { suggested } \\
\text { tools); Nursing }\end{array}$ & $\begin{array}{l}\text { Educational } \\
\text { workshop }+ \\
\text { toolkit of } \\
\text { measures } \\
\text { Dose: } 4\end{array}$ & $\begin{array}{l}\text { Use: Improved from } \\
26 \% \text { to } 41 \% \text { use in } \\
\text { intervention, and } 45 \% \\
\text { to } 48 \% \text { in control. } \\
\text { Attitudes: No effect }\end{array}$ \\
\hline
\end{tabular}




\begin{tabular}{|c|c|c|c|c|c|c|}
\hline & & & & $\begin{array}{l}\text { homes (14 } \\
\text { suggested } \\
\text { tools) }\end{array}$ & $\begin{array}{l}\text { interactive } \\
\text { half-day } \\
\text { sessions over } \\
4-5 \text { months }\end{array}$ & \\
\hline $\begin{array}{l}\text { van Peppen, } \\
2009(31) \\
\text { Netherlands }\end{array}$ & $\begin{array}{l}\mathrm{PT} \\
\mathrm{n}=30(15 \\
\text { experimental } \\
\text { and } 15 \text { control })\end{array}$ & $\begin{array}{l}\text { Pilot } \\
\text { randomized } \\
\text { controlled } \\
\text { trial }\end{array}$ & $\begin{array}{l}\text { Stroke } \\
\text { Acute, } \\
\text { rehabilitation, } \\
\text { community }\end{array}$ & $\begin{array}{l}\text { Multiple, } n=7 \\
\text { (e.g., Berg } \\
\text { Balance Scale, } \\
\text { Barthel Index) }\end{array}$ & $\begin{array}{l}\text { Educational } \\
\text { program by } \\
\text { non-expert } \\
\text { (control); } \\
\text { education by } \\
\text { expert } \\
\text { (intervention) } \\
\text { Dose: } 10 \\
\text { hours }\end{array}$ & $\begin{array}{l}\text { Use: Median (number } \\
\text { of outcome measures } \\
\text { used) in experimental } \\
\text { group (6) higher than } \\
\text { in control group (4), } \\
p=.07 \\
\text { (actual use) }\end{array}$ \\
\hline
\end{tabular}

Notes: Occupational Therapists (OT), Physiotherapists (PT), Speech Language Pathologists (SLP), audit and feedback (A\&F); Gross

Motor Function Classification System (GMFCS); Gross Motor Function Measure (GMFM-88 and GMFM-66); Motor Growth Curves

(MGCs); Pediatric Evaluation of Disability Inventory (PEDI), Timed 'Up and Go' Test (TUG), Timed Up and Down Stairs Test

(TUDS) 
Table II Summary of quality assessment

\begin{tabular}{|c|c|c|c|c|c|c|c|}
\hline First author, date & $\begin{array}{l}\text { Selection } \\
\text { Bias }\end{array}$ & $\begin{array}{l}\text { Study } \\
\text { Design }\end{array}$ & Confounders & Blinding & $\begin{array}{l}\text { Data } \\
\text { Collection } \\
\text { Method }\end{array}$ & $\begin{array}{l}\text { Withdrawals } \\
\text { and } \\
\text { Dropouts }\end{array}$ & $\begin{array}{l}\text { Overall } \\
\text { rating }\end{array}$ \\
\hline Abrams, 2006 (1) & Moderate & Weak & Weak & Weak & Weak & Weak & Weak \\
\hline Bland, 2013 (32) & Moderate & Weak & Weak & Moderate & Weak & $\mathrm{N} / \mathrm{A}$ & Weak \\
\hline Cook, 2007(30) & Weak & Weak & Weak & Weak & Weal & Weak & Weak \\
\hline $\begin{array}{l}\text { Gaunaurd, } 2015 \\
\text { (27) }\end{array}$ & Moderate & Weak & Weak & Weak & Weak & Weak & Weak \\
\hline Käll, 2016 (35) & Moderate & Moderate & Moderate & Weak & Moderate & Moderate & Moderate \\
\hline Kisely, 2008 (25) & Moderate & Weak & Weak & Weak & Weak & Weak & Weak \\
\hline Russell, 2010 (34) & Moderate & Weak & Weak & Weak & Weak & Weak & Weak \\
\hline $\begin{array}{l}\text { Schreiber, } 2015 \\
\text { (28) }\end{array}$ & Moderate & Weak & Weak & Weak & Weak & Weak & Weak \\
\hline Sumner, 2000 (33) & Weak & Moderate & Weak & Weak & Weak & Weak & Weak \\
\hline Swinkels, 2015 (29) & Weak & Moderate & Weak & Weak & Weak & Weak & Weak \\
\hline
\end{tabular}




\begin{tabular}{|l|l|l|l|l|l|l|l|}
\hline Van Peppen, 2009 & Moderate & Strong & Strong & Moderate & Weak & Strong & Moderate \\
$(31)$ & & & & & & & \\
\hline
\end{tabular}


Objective: To determine the types and effectiveness of interventions to increase the knowledge about, attitudes towards, and use of standardized outcome measures in rehabilitation professionals. Data Sources: An electronic search using Medline, EMBASE, PsycINFO, CINAHL, Ergonomics Abstracts, Sports Discus. The search is current to February 2016. Study Selection: All study designs testing interventions were included as were all provider and patient types. Two reviewers independently conducted a title and abstract review, followed by a full-text review. Data extraction: Two reviewers independently extracted a priori variables and used consensus for disagreements. Quality assessment was conducted using the Assessment of Quantitative Studies published by the Effective Public Health Practice Group. Data Synthesis: We identified 11 studies involving at least 1200 providers. Nine of the studies showed improvements in outcome measure use rates but only three of these studies used an experimental or quasi-experimental design. Eight of the studies used an educational approach in the intervention and three used audit and feedback. Poor intervention description and quality of studies limited recommendations. Conclusions: Increased attention to testing interventions focused on known barriers, matched to behavior change techniques, and with stronger designs is warranted. 